\title{
Bt cotton infestations renew resistance concerns
}

Reports of insect pests making serious inroads in commercial plantings of genetically engineered cotton in Texas drove down the market value of the Delta and Pine Land Company (DPL; Scott, MI) stock so sharply-its price plummeted six points during a mid-July session - that the New York Stock Exchange temporarily halted trading of stock on the cotton seed supplier. However, more importantly for agricultural biotechnology, the infestation reports have prompted questions about whether resistance management plans can protect the long-term utility of crops carrying Bacillus thuringiensis (Bt)-derived insecticidal genes. Environmentalists at the Union of Concerned Scientists (Washington, DC) are already urging the US Environmental Protection Agency (EPA, Washington, $D C$ ) to suspend registration and sales of $B t$-engineered cotton pending development of an alternative resistance management plan - "one that will work." EPA has asked Monsanto to prepare a formal report following on-site evaluation of the Bt cotton fields in Texas.

Through an agreement with Monsanto (St. Louis, MO) covering the use of Bollgard, the company's Bt-containing gene constructs, DPL this year supplied $B t$ engineered cotton seeds for some 2 million acres of US farmland-representing a high first-year penetration of an estimated 5-million acre overall market. However, there have been unusually high infestations of cotton bollworm in Texas and elsewhere in this first year of extended planting.

Monsanto representatives attribute the infestation to the extremely hot and dry conditions in the region; the bollworm is simply "overwhelming the Bt." There are no signs that the pest is developing resistance to the insecticide, they argue. "We're still getting $95 \%$ control, but the insect populations are much higher than usual this year," points out Monsanto's Roy Fuchs, "We're collecting insects and monitoring to determine whether susceptibility to $B t$ is changing." The company also stresses that although the Bollgard version of the $B t$ toxin does control the cotton bollworm, the major pest targets in cotton are the tobacco budworm and the pink bollworm, pests which attack the crop later.

"The [infestation] situation does not surprise me," says entomologist William McGaughey of the US Department of Agriculture (USDA) Agricultural Research Service (Manhattan, KS), pointing to the initial experience with Bollgard in the cotton belt. "When you have high infestation pressures, doses that ordinarily give apparent $100 \%$ control often look bad." The extreme tem-

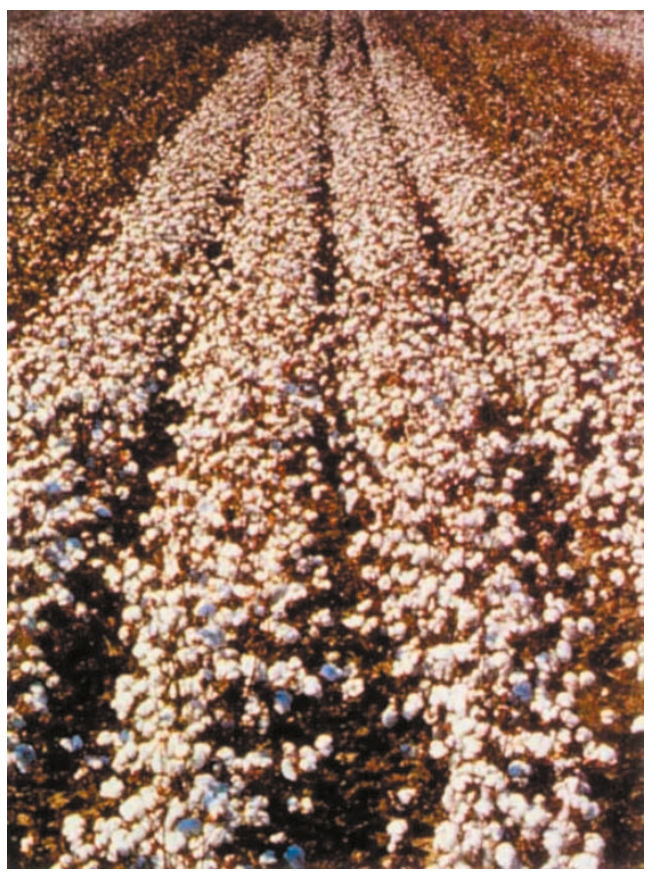

Commercial plantings of genetically engineered cotton. It is not yet clear whether Bt-engineered cotton will lead to the emergence of resistant pests.

peratures may also have indirectly affected the $B t$ crops. "Natural protein synthesis in plants is sometimes altered under heat and drought stress," says McGaughey, "It seems

\section{Monsanto representatives attribute the infestation to} the extremely hot and dry conditions in the region; the bollworm is simply "overwhelming the Bt." There are no signs that the pest is developing
resistance, they argue.

logical that expression of this insecticidal protein would be altered as well."

There is wide agreement that resistance to $B t$ has not been detected among the insects infesting the Texas cotton plants. But some critics contend that this first large-scale field experience with cotton brings into question the adequacy of current resistance management.

One of the main strategies to preserve $B t$-sensitivity entails the use of "refugia"areas within and near $B t$-producing plants that are purposely left untreated to reduce selective pressure on the pests to develop resistance. The refugia need to constitute $4-20 \%$ of a given crop, according to Fred Gould of North Carolina State University (Raleigh, NC). "The refuge of $4 \%$ required by the EPA for Monsanto cotton (or the $20 \%$ sprayed refuge) seemed just about adequate for the tobacco budworm, Heliothis virescens, which is a major pest of cotton," he says. This pest is "very susceptible" to $B t$, so if $4 \%$ of the land is set aside to serve as a "refuge," Bt-susceptible insects may continue to thrive there. However, Gould points out, "The cotton bollworm, Helicoverpa zea is less sensitive to the toxin, so it is misleading to use this cotton in a high-dose refuge approach for the bollworm." A true high-dose strategy would approach $100 \%$ mortality, but in several sets of field tests, $B t$ cotton killed only about $80 \%$ of the bollworm. "Indeed," Gould continues, " $80 \%$ mortality is exactly what researchers use when they want to breed resistant insects." So with less susceptible insects, a much larger refuge-up to $20 \%$ of the overall crop-may be required to slow resistance. Under ordinary circumstances, fields of corn (maize) could serve as refugia for resistance management on Bt-cotton; the cotton bollworm, also known as the corn ear worm, feeds on corn, too. But there is a complication. Next year, corn marketed by Northrup King (Minneapolis, MN) will also contain a $B t$ gene and will produce insecticidal toxin in the ears where the corn ear worm feeds. "Thus corn will no longer be a refuge..." says Gould. "This is not a good situation."

Anticipating this concern, in August, the EPA imposed restrictions on the corn's distribution in the southern US states in order to conserve the effectiveness of $B t$ cotton. EPA officials rationalize that the losses to cotton from corn ear worm resistance to $B t$ in the South, and corn and other crops in the North "would greatly outweigh the benefits to field corn in the South." "We understand the reason behind the EPA decision, but we would like to sell our $B t$ corn in the South," says Northrup King's William Pilacinski. The company plans to bring additional data to the agency, hoping to have restrictions eased in parts of the South where corn is more widely grown than cotton. But this process could take several years, says Pilacinski. Meanwhile, he says, in placing such broad limits on the company's engineered corn, EPA appears to have "chosen cotton over corn growers in the South."

Jeffrey L. Fox 